\title{
THE IMAGERY OF BIRTH PANGS IN THE NEW TESTAMENT ${ }^{1}$
}

\author{
Conrad Gempf
}

\begin{abstract}
Summary
It is perhaps surprising that in the patriarchal culture of first century Palestine, male teachers such as Jesus and Paul should speak or write to ostensibly predominantly male audiences using as an image a pain that has never been felt by males. The reason for this particular image is often presumed to be that birth pangs are a pain that lead to a positive result, but, especially given the Old Testament use of the image, this is unlikely to be the primary meaning for the image. Alternatives are explored: birth pangs, as well as being a 'productive' pain, are an 'intense' pain, a 'helpless' pain, and a 'cyclical' pain that once begun must run its course.
\end{abstract}

\section{Introduction}

One of the most pervasive modern images of Christianity is that of being 'born again'. But this 'new birth' tends to be a very idealised business with a lot of the unpleasantness of the real life birth process left out of the picture. One rather expects that in the culture of the biblical world, even more patriarchal and andro-centric than our own, the intense period of suffering that follows the long months of discomfort would be skipped over lightly, since it never happens to the men who shape the tradition, but only to the women, whose 'job' it is sometimes seen to be. The account of birth found in the Wisdom of Solomon (7:1-5) seems typical of this skipping over of the pain:

I also am mortal like everyone else, a descendant of the firstformed child of earth; and in the womb of a mother I was moulded into flesh, within a period of ten months, compacted

${ }^{1}$ The Tyndale House New Testament Lecture for 1993. 
with blood, from the seed of a man and the pleasure of marriage. And when I was born, I began to breathe the common air, and fell upon the kindred earth; my first sound was a cry, as is true of all. I was nursed with care in swaddling clothes. For no king has had a different beginning of existence; there is for all one entrance into life, and one way out.

Certainly main-line English-speaking scholarship of the past century or so has tended to pass over such events quickly and blushingly and on to the event of the birth itself. Many books about 'Life and Culture in the Roman Empire' leap from a paragraph about marriage, with perhaps a sentence about sex within marriage, to the rituals and responsibilities of brandnew parents. Books that discuss pregnancy or labour or delivery are hard to find and on the fringe.

The Bible expresses no such reticence, and the matter of birth-pains is mentioned explicitly from Genesis to Revelation, and used as an important image in various strands of New Testament tradition: Paul, the Synoptics, John and Revelation. There seems a need for a survey of the uses to which this image is put-a survey that makes distinct several facets of the image that modern scholarship seems to blur together. Taking the image of birth-pains seriously might add to our understanding of these New Testament passages. ${ }^{2}$

${ }^{2}$ There are few articles or books that cover this specific image. The

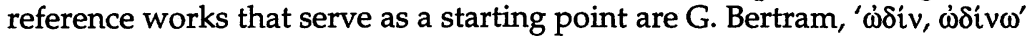
TDNT IX, 667-674 and comments in Strack and Billerbeck, Kommentar zum Neuen Testament als Talmud und Midrasch IV.2 Exkurs 29 and, for example, pp. 1042f. and 1067. It is certainly time for more research on 'birth pangs of the Messiah' within the modern understanding of Judaism, and incorporating some of the recent evidence. Recent secondary literature in the NT field related to this topic is usually primarily concerned with other things, and only touches upon 'birth pangs'. Of especial significance, however, is D.C. Allison, Jr., The End of the Ages Has Come (Philadelphia: Fortress, 1985). His concern is to show that the sufferings experienced by Jesus and the disciples were regarded in the Gospels as part of the 'messianic woes'. There is an important discussion of 'birth pangs' including analysis of extra-canonical passages in the first chapter of the book. R.H. Gundry's recent Mark: A Commentary on His Apology for the Cross (Grand Rapids: Eerdmans, 1993) also provides interesting discussion and references; see especially p. 763. He approaches the matter in the light 


\section{Intense Pain}

The most obvious reason for using the image of birth pangs is that the pain of childbirth is such an intense and total pain, and one that virtually everyone will have some knowledge of. So basic is it to Jewish, indeed all human, experience that chapter 3 of Genesis specifically mentioned pain in childbirth as one of the curses of the Fall, along with the necessity of toil and of death.

The pagan world of the first century also knows and fears this pain. Artemis is the patron goddess of childbirth ${ }^{3}$ but there was another goddess whose very name was a reference to the pains of labour, Ilithyia, to whom there were dedicated a considerable number of sanctuaries. 4 The dedicatory inscriptions to this goddess are revealing: 'Once more, Ilithyia, come at Lycaenis' call, easing thus the pangs of labour...' ${ }^{5}$ or 'Blest Ilithyia, receive and keep as thy fee for delivering Tisis, who well remembers, from her pangs, this bridal brooch and the diadem from her glossy hair', 6 or 'Ilithyia, at thy glorious feet Ambrosia, saved from the bitter pangs of labour, laid her head-bands and her robe, because that in the tenth month she brought forth the double fruit of her womb'.7 While the birth of a child is often mentioned, it seems secondary in the dedications-secondary to the mother being brought through the intense and bitter pains of childbirth.

of Mark 13:8, of course, and with the conviction that Mark's image is distinct from 'the travail of the Messiah'.

In this discussion of the use of birth pangs and pain as imagery, we shall usually leave to one side other passages such as $1 \mathrm{Tim}$. 2:15, which deal not with the pain, but with the actual birth, and perhaps literally rather than as an image. On this difficult verse, however, see now S.E. Porter, 'What does it mean to be "Saved by Childbirth" (1 Timothy 2:15)?', JSNT 49 (1993) 87-102.

${ }^{3}$ S.B. Pomeroy, Goddesses, Whores, Wives and Slaves: Women in Classical Antiquity (London: Hale, 1975) 5.

${ }^{4} \mathrm{H}$. Licht, Sexual Life in Ancient Greece (London: Routledge, 1956) 214-215.

5W.R. Paton, Greek Anthology (5 vols.; Loeb Classical Library; London: Heinemann, 1960-1970) VI.146 (dedicatory epigrams).

6Paton, Anthology VI.274.

7Paton, Anthology VI.200. 
It is worth noting that labour is not merely a time of severe pain, but also a time of distinct peril in the ancient world. 'The head-kerchief and water-blue veil of Amphareta rest on thy head, Ilithyia; for them she vowed to thee when she prayed thee to keep dreadful death far away from her in her labour. ${ }^{\prime}$ In his play Medea, Euripides has the female main character protest that she would rather stand in the front line of battle three times than to go through childbirth once. 9

Such an image does not go unused in the biblical texts. Both pain and peril are clear in Jeremiah 4:31: 'I hear a cry as of a woman in labour, a groan as of one bearing her first childthe cry of the daughter of Zion gasping for breath, stretching out her hands and saying "Alas I am fainting; my life is given over to murderers."' In speaking about God's judgement, Jeremiah 30 uses various images for pain, including sores and wounds (Je. 30:12-15), but arguably the most successful is the remarkable verses 4-7:

Cries of fear are heard-terror, not peace. Ask and see: can a man bear children? Then why do I see every strong man with his hands on his stomach like a woman in labour, every face turned deathly pale? How awful that day will be! None will be like it.

Later tradition also picks up this image for the intensity of pain of God's judgement. Allison, in his recent study, has argued that the OT connection between the day of the Lord and birth pain/tribulations is carried into the later period. ${ }^{10}$ In 1 Enoch 62:4-6, it is kings, governors, high officials and landlords who will be struck: "The pains shall come upon them as on a woman in travail with birth pangs-when she is giving birth (the child) enters the mouth of the womb and she suffers from childbearing'. Again it is striking that although the mechanics

8Paton, Anthology VI.270.

${ }^{9}$ Euripides, Medea 248-251.

${ }^{10}$ Allison, The End of the Ages Has Come; see especially p. 6, where he responds to J.C. Beker's surely erroneous claim that the use of the term 'messianic woes' arose only in the middle to late second century (Paul the Apostle: The Triumph of God in Life and Thought [Philadelphia: Fortress, 1980] 146). 
of a child being born are mentioned, they are description. The birth itself is not really part of the imagery-no figurative child is born to these kings, governors et al.

This is the sort of image employed by the New Testament when the apostle Paul writes to the Thessalonians: '...the day of the Lord will come just like a thief in the night. While they are saying, "Peace and safety!" then destruction will come upon them suddenly like birth pangs upon a woman with child; and they shall not escape'. Again, it is unlikely that there is any thought of the 'they' having these birth pangs because they are bearing some child, figuratively speaking. The anguish of the pains is all they have. 11

It seems to many writers, rightly, that Paul is dependent upon the Gospel traditions for this set of images and for his eschatology generally. ${ }^{12}$ In Mark 13, the image of birth pains is used to describe several terrible and painful kinds of events, strife and earthquakes and famines. These, Matthew and Mark tell us, are the beginning of the birth pains, perhaps implying that the bitter pains will get even worse than that.

Romans 8 is another Pauline passage that speaks of suffering in terms of the pains of childbirth. The whole of creation, Paul tells us, has been in the pains of childbirth right up to the present time. As is frequently the case in birth pangs imagery, it is not just the opponents of God who feel this pain, but the faithful as well: 'We ourselves, who have the first-fruits of the Spirit, groan inwardly...'

Concerning this passage, Bertram writes: 'All creation waits together for the rebirth, the new birth of the world...'13 The text does indeed speak of this waiting (vv. 19, 23), right alongside the pain and frustration (vv. 18, 20), but it is not easy to find the images resolving themselves into a birth or rebirth in

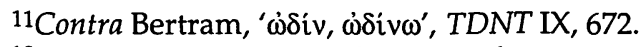

${ }^{12}$ In connection with 1 Thes. 5:3, Lk. 21:34 is often cited as a particularly close parallel: see for example, I.H. Marshall, 1 and 2 Thessalonians (Grand Rapids: Eerdmans, 1983) 134; C.A. Wanamaker, The Epistles to the Thessalonians (Exeter: Paternoster, 1990); E. Best, The First and Second Epistles to the Thessalonians (London: A. \& C. Black, 1972) and D. Wenham, 'Paul and the Synoptic Apocalypse', in R.T. France and D. Wenham (eds.), Gospel Perspectives II (Sheffield: JSOT Press, 1981).

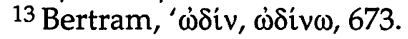


the text itself. Verse 19, with the talk of 'sons' seems hopeful, but oddly, after the introduction of the image of 'birth pangs' in verse 22 , the next verse clarifies that the 'sons' are not natural ones but 'adopted'. It is surprising that this juxtaposition or mixed metaphor of birth pangs and adopted children goes unnoticed in most of the commentaries. ${ }^{14}$ 'We ourselves, who have the first-fruits of the Spirit, groan inwardly as we wait eagerly for adoption as sons.' The passage does not speak of the expected birth event, nor is there any talk of the Spirit as a sort of midwife, which might be expected. Clearly, although the passage as a whole speaks of hope, the particular image of 'birth pangs' concerns pain and futility. Creation undergoes this, the human race was cursed by being subjected to it (Gen. 3), but it is now God the Spirit who feels it in our stead or alongside us in a sort of reversal of the curse..$^{15}$ In this passage, as in many others, the image of birth pains focuses primarily on the present pain and the frustration and is not forward-looking except in looking to the end of this pain and frustration (v. 21). The message is not 'this pain will produce a future good', but rather 'the present agony will not always be with us'.

\section{Helpless Pain}

Romans 8 picks up a major emphasis in the Old Testament usage of this image: that of helplessness and frustration in labour pains. We cannot deny that the image is sometimes used by the biblical authors in the sense of intense suffering leading to some positive result, but it is astonishing how often birthpangs are used as an analogy for suffering and helplessness without any thought of a coming child.

The primary sense is made clear in a passage already considered, Jeremiah 30: 'can a man bear children? Then why

14 See, for example, C.K. Barrett, The Epistle to the Romans (London: A. \& C. Black, 1962) 167; C.E.B. Cranfield, Romans Vol. 1 i-viii (Edinburgh: T. \& T. Clark, 1975); D. Moo, Romans 1-8 (Chicago: Moody, 1991) and J.D.G. Dunn, Romans 1-8 (Dallas: Word, 1988).

15I am grateful to Richard Riggall for pointing out this 'reversal' motif.

16 See the similar references for Edom (49:22), Damascus (49:24) and the king of Babylon (50:41-43). 
do I see every strong man with his hands on his stomach like a woman in labour, every face turned deathly pale?' Time and again in the Old Testament, faced with armies of judgement, the prophets in particular tend to describe the men of the opposition turning into vulnerable, labouring women.

Listen! A noise on the mountains, like that of a great multitude!... The Lord Almighty is mustering an army for war... Because of this all hands will go limp, every man's heart will melt. Terror will seize them, pain and anguish will grip them; they will writhe like a woman in labour. They will look aghast at each other, their faces aflame. (Is. 13:4-8)

Look! An eagle is swooping down, spreading its wings over Moab...In that day the hearts of Moab's warriors will be like the heart of a woman in labour. (Je. 48:41) 16

When the kings joined forces, when they advanced together, they saw and were astounded; they fled in terror. Trembling seized them there, pain like that of a woman in labour. (Ps. 48:4)

The Lord will march out...with a shout he will raise the battle cry...For a long time I have kept silent, I have been quiet and held myself back. But now, like a woman in childbirth, I cry out, I gasp and pant. (Is. 42:13-14)

A passage from Qumran (1 QH 5) is similar:

They have overtaken me in a narrow pass without escape and there is no rest for me...Anguish seizes me like the pangs of a woman in travail, and my heart is troubled within me.

The point is clear. These are not passages about eschatological hope. There is no thought that although the kings who joined forces are suffering now, they will give birth to a new age of peace and tranquillity. These are, rather, images of pain, despair, and even humiliation. ${ }^{17}$ The connection with the

${ }^{16}$ See the similar references for Edom (49:22), Damascus (49:24) and the king of Babylon (50:41-43).

17In some passages in Jeremiah, one wonders if this labour might not be used to imply the outcome of Judah's 'whoring with the nations': 'What 
judgement motif in 1 Thessalonians 5 is again clear. This, rather than apocalyptic hope, is the background to Paul's use of the image of 'the creation is subject to frustration', the pains in Romans 8, and the reason why, to bring in hope, he feels he must mix his metaphors. In Romans 8 and 1 Thessalonians 5, as in these passages from the Psalms and Prophets, the pain of child-birth is not a positive but a negative image.

\section{Productive Pain}

I have had to stress the negativity to make the point that the image is not always used in a way that looks forward. Whenever we see the image of birth-pangs, we cannot assume that the writer is thinking about a new birth, just as when we read the image of new birth, we cannot assume that birth-pangs and pain and frustration are also in the background. But there are, of course, passages that combine these two images in a very natural way.

The pain and frustration leading to the birth of a new age seems a powerful symbol in the New Testament, and is firmly rooted in Jewish tradition. At first glance a positive passage like John 16:21 seems miles away from the Old Testament use of birth pangs as describing the humiliation of the enemy:

I tell you the truth, you will weep and mourn while the world rejoices. You will grieve, but your grief will turn to joy. A woman giving birth to a child has pain, because her time has come; but when her baby is born she forgets the anguish because of her joy that a child is born into the world. So with you: Now is the time of your grief, but I will see you again and you will rejoice and no one will take away your joy. (Jn. 16:20-22)

will you say when the Lord sets over you those you cultivated as your special allies? Will not pain grip you like that of a woman in labour? If you ask yourself "Why has this happened to me?" it is because of your many sins...' (Je. 13:21-22, cf. 22:20-23). 
Rather than the pangs and the helplessness of God's opponents, the emphasis here is on the birth and the joy that follows the bad times. This seems to be an image of birth, with the birthpangs a subsidiary part of that other image.

But perhaps this is not so very distant after all. At least, a line of connection can be traced. From the humiliation of earthly, present enemies, there is an obvious connection to the eschatological defeat of all God's opponents. And in an apocalyptic mind-set, those opponents are an all-pervasive force, inescapable in this world (which is why God must intervene). In a sense the enemies who will be humiliated are the world, the whole of the cosmos. But something good will occur. The Phoenix image of something arising out of the ashes springs to mind, of course. But if one is already using the image that the 'world' will be defeated and humiliated by God and their pain will be as birth pains, then what could be more natural than to describe the coming of the good, the new age, as the birth?

Sometimes it is the frustration of an 'unproductive' birth process that the Old Testament appears to have in mind:

As a woman with child and about to give birth writhes and cries out in her pain, so were we in your presence, $\mathrm{O}$ Lord. We were with child, we writhed in pain, but we gave birth to the wind. We have not brought salvation to the earth... (Is. 26:1718)

Pains as of a woman in childbirth come to him, but he is a child without wisdom; when the time arrives, he does not come to the opening of the womb. (Ho. 13:13)

The major passages from Isaiah and Micah, however, present a very positive image, an image that was to be influential for the Christians and the rabbis:

Hear the uproar from the city, hear that noise from the Temple! It is the sound of the Lord repaying his enemies all they deserve. Before she goes into labour, she gives birth; before the pains come upon her, she delivers a son. Who has ever heard of such a thing? Who has ever seen such things?... no sooner is Zion in labour than she gives birth to her 
children. 'Do I bring to the moment of birth and not give delivery?' says the Lord. (Is. 66:6-9)

Micah similarly looks forward to a birth that means restoration:

Writhe in agony, $\mathrm{O}$ daughter of Zion, like a woman in labour, for now you must leave the city to camp in the open field. You will go to Babylon; there you will be rescued...Therefore Israel will be abandoned until the time when she who is in labour gives birth and the rest of his brothers return to join the Israelites... and they will live securely, for then his greatness will reach to the ends of the earth. (Mi. 4:10; 5:3-4)

Christians are not alone in picking up on these uses of the image and applying them messianically. In $1 \mathrm{QH} 3$ (the Thanksgiving Hymns) there is an extended passage which makes this interpretation explicit:

...like a woman in travail with her first-born child, upon whose belly pangs have come and grievous pains, filling with anguish her womb. For the children have come to the throes of Death, and she labours in her pains who bears a man. For amid the throes of Death she shall bring forth a man child, and amid the pains of Hell there shall spring from her womb a Marvellous Mighty Counsellor...

There are, of course, great difficulties with using the rabbinic literature with confidence to speak about early traditions, but the way that the image is used in passages such as bSanhedrin 97-98, shows that rabbinic Judaism had firmly adopted a concept which it found distasteful: that the Messiah would be preceded by birth-pain. The arguments there are not over whether such a thing is true, but over how one might avoid these pains without seeming not to desire Messiah's coming. ${ }^{18}$

\footnotetext{
${ }^{18}$ Strack-Billerbeck, Kommentar, is, as one might expect, a useful starting point for discussions of the rabbis in relation to this theme; surprisingly, however, they do not comment on the passage in Jn. 16, but rather upon the reference to birth-pangs in Mt. 24, which seems less like the rabbinic use, though more like the predominant OT use. See also the discussions of Bertram, TDNT 670ff. and Allison, The End of the Ages, 5-25.
} 
There is, in Christian uses of the image, no thought, no hope of avoiding these pains. In John's gospel, one has to look past them to what is to come for the strength to endure them. It is interesting to note that in John, it is not the world and creation that is groaning and giving birth. Just who is is a matter of some debate; 19 but for our purposes it is sufficient to recognise that somehow, these sufferings have to do with the forces of good rather than the enemies of God or the world at large, as is the case in Romans 8 or Mark 13 and its parallels. Instead it seems much more in line with the use of the image in Revelation 12:

...a woman clothed with the sun, with the moon under her feet and a crown of twelve stars on her head. She was pregnant and cried out in pain as she was about to give birth...The dragon stood in front of the woman...so that he might devour her child the moment it was born. She gave birth to a son, a male child, who will rule all the nations... and the child was snatched up to God and his throne. And the woman fled into the desert to a place prepared for her by God. (Rev. 12:1-6)

Here clearly the birth rather than the pain is the controlling image. In contrast to this stands another mixed metaphor from Paul to the Galatians: 'My dear children, for whom I am again in the pains of childbirth until Christ is formed in you' (4:19). Betz goes to incredible lengths to tie Paul's 'motherhood' of the community to the secular 'friendship' complex and to Gnosticism.20 Even Longenecker focuses on the birth and 'formation' of Christ: '...Paul's birth pangs are seen as having to do with forming again the body of Christ in a corporate

${ }^{19}$ Lindars seems to be wrong in seeing the question of who suffers as insignificant (B. Lindars, The Gospel of John [NCB; London: Oliphants, 1972] 509). See the entertaining description of the various views in R.E. Brown, The Gospel According to John, XIII-XXI (London: Chapman, 1966) 732, and Allison, The End of the Ages, 57-61.

${ }^{20}$ H.-D. Betz, Galatians (Philadelphia: Fortress, 1979) 233-234, citing such sources as Plato, Aristotle, Plutarch and Cicero on the one hand, and Hermes Trismegistos on the other. 
sense in the Galatian community'. ${ }^{21}$ But in the light of our study thus far, it seems most likely that the controlling image here is not the birth, but the pangs. Paul's sense of surprise and his perplexity are seen throughout the letter (cf. 1:6; 3:1-3; 4:9; 5:7), and having one's hands go limp and to be in childbirth pains are a good image to use for this. Paul is thus, perhaps, primarily expressing his feelings of helplessness and pain, and then extending the metaphor and analogy into birth imagery. That, after all, is the thrust with which Paul ends his sentence:

My dear children, for whom I am again in the pains of childbirth until Christ is formed in you-I wish I could be with you now and to change my tone, for I am perplexed about you.

\section{A Pain that Must Run its Course}

But there is another aspect to the image of birth pains that is much neglected. In some ways this is related to the 'helplessness' mentioned earlier. One who is gripped by labour pains is not just dominated and wracked by pain for a moment. They are dominated by a series of events. It is more than a pain; it is a process, a cycle; it is a pain or series of waves of pain that must run their course.

To some extent, this is implied in the passage in John's gospel already examined: 'When a woman is in travail she has sorrow because her hour has come...' Here $̋ \rho \alpha$ may well be used to indicate a space of time. Note that it is used here without the word $\mu i \alpha$, which is used in passages such as Revelation 18:10 or Mark 14:37 ('...could you not keep watch for one hour?') to emphasise the shortness of the time. It is more like the usage in the Gospels for Jesus' hour having come. And, suggestively, his 'hour' is also an hour of suffering.22

${ }^{21}$ R.N. Longenecker, Galatians (Dallas: Word, 1990) 195. His suggestion that Phm. 10, and perhaps also 1 Cor. 4:15 are roughly parallel in that Paul regards himself there as a 'father begetting children' has some merit, however.

22See Allison, The End of the Ages, 57ff. 
The Old Testament, too, knows of the 'hour of travail' as a period of time. The time of labour pangs and the moment of birth are, as we have seen, distinct. Thus Rachel's death while giving birth to Benjamin is described with some measure of realism in Genesis 35:16-18. But it is not just passages that are literally about giving birth that betray this distinction. In 2 Kings 19:3, the king Hezekiah is reported to have used the symbol this way: "This day is a day of distress and rebuke and disgrace, as when children come to the time of birth and then there is no strength to deliver them'.

Perhaps most clear of all is Micah 4:9-10 in connection with 5:3 ('Therefore Israel will be abandoned until the time when she who is in labour gives birth'). Despite the use that we have seen Qumran and rabbis make of these verses, there is much dispute about the events to which this image was originally meant to refer. Mays, for example, argues cogently that it is not what we might think of as a messianic predictionthat the period of labour pains is the exile and the 'birth' is the return to Israel, but the birth is not what is being emphasised. The real point of the passage is this intermediate period of pangs before the birth. 23

Similarly the rabbis spoken of in the Talmud appear to have wished to be spared seeing the Messiah's coming in order to be spared the distinct but connected period of suffering before-the 'birth pain of the Messiah'.24 The book of 2 Esdras, also written after the New Testament, provides a passage which clearly links this sense of a period of pain with the 'helplessness' theme and the cosmic referent for the sufferer that we saw in Paul's writings. 2 Esdras 16:37-39 reads:

The calamities draw near and are not delayed. Just as a pregnant woman, in the ninth month when the time of her delivery draws near, has great pains around her womb for two or three hours beforehand, but when the child comes

${ }^{23}$ See J.L. Mays, Micah (London: SCM, 1976) 205-206. Compare however Hillers, Micah (Philadelphia: Fortress, 1984) 66, who argues for a quite different emphasis.

${ }^{24}$ Not only the passage we have discussed, bSanhed. 97-98, but also $b K e t h u b .111 a$, and $b S a b b .118$ contain discussions of who will be spared these birth pains and why. 
forth from the womb, there will not be a moment's delay, so the calamities will not delay in coming upon the earth, and the world will groan, and pains will seize it on every side.

The pangs of childbirth are not only a terribly intense pain, and not only a pain that dominates the sufferer and makes them helpless-it is a pain that grips the sufferer and forces the sufferer to go through a prescribed pattern (even if not of predetermined length). The birth pangs are a pain that, once it has begun, must run its course to completion, regardless of what happens to mother or child along the way. ${ }^{25}$

This is very similar to the way the image is also used in Mark 13:8 and its close parallel in Matthew 24. There is a period before the very end that leads inescapably to the end, but is not itself the end:

Such things must happen, but the end is still to come. Nation will rise against nation, and kingdom against kingdom. There will be earthquakes in various places, and famines. These things are [merely] the beginning of birth pains.

Hooker remarks wryly: 'The purpose of Mark 13 seems, indeed to be to urge inaction rather than action...'26 Jesus, faced with a question about the destruction of the temple to which one might have expected a full-blown apocalyptically-styled answer, replies in a way that does indeed include apocalyptic imagery, but with some things that are grossly unsuitable for an apocalyptic timetable. Perhaps this 'false start' (the end is not yet) might fit into an ordinary apocalyptist's writing were it not followed later in the speech by that remarkable statement of the Markan Jesus that he does not know when the end will be. This is an admission no good apocalyptist would make, and certainly not what the disciples would have expected their Lord to say. We might add parenthetically that it is also extremely unlikely that, left to their own devices, the early church would have tried to solve their problem of a felt delay of the parousia by appealing to Jesus' ignorance in the matter!

${ }^{25}$ See also Acts 2:24 for this use of $\dot{\omega} \delta i v$.

26M. Hooker, St. Mark (London: A. \& C. Black, 1991) 300. 
Yet, before admitting to them that they and he cannot know the day and hour, he has told them they may know the beginning of the birth pains and when the summer is near. Surely there is something of a paradox in saying that you will be able to know the signs of the times but not know the time. There may be a clue in the form of the word used here. We have seen that the 'birth pain of the Messiah' became a technical term for the period of suffering out of which Messiah

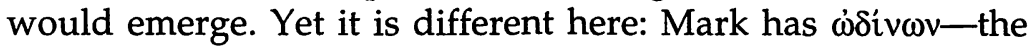
plural. This difference has been pointed out by not a few scholars, but only as a reason for thinking that the tradition behind Mark has developed out of the prophetic literature independently of the rabbinic tradition. 27

It seems possible that the plural was used for a more obvious purpose-to highlight a facet of birth pains that we have not yet mentioned: the pain of childbirth is not a steady pain, nor a steadily increasing pain, but a repeating phenomenon, coming in waves over and over again. And, except in Isaiah 66, the baby does not come on the first pang. With the first one, you know that the inexorable process has begun, but you do not know that the baby will come on the 5th wave, or the tenth or the twentieth. You know that the time is near, but not how near. Periods of wars and rumours of wars may come and go like birth pangs. Many of the signs mentioned are repeated in history, notably the 'Abomination of Desolation', which might have well referred to a number events prior to the New Testament period. You can know when the time is ripe, but the baby appears when the baby appears, and throughout the labour, you must be on your guard.

Certainly this is not how the rabbis used the figure, but, as has been pointed out, neither did they use the plural. This meaning fits in so well with the other notable characteristics of the discourse that it must be regarded as a possibility.

${ }^{27}$ See, for example, Bertram, TDNT 672; G.R. Beasley-Murray, A Commentary on Mark Thirteen (London: Macmillan, 1957) 38; and most recently, Gundry, Mark, 763. 


\section{Conclusion}

Thus we have seen that the image of birth-pains is an image that the New Testament writers have picked up from the Old Testament. It is used in a variety of ways and makes a number of distinct, if related, points. It is used in the first instance to make plain the acuteness of the pain and suffering. It is a pain that many people may well have seen the effects of, if not experienced first hand, even in a male-orientated culture. ${ }^{28}$

But it is not merely an intense pain, it is one which renders the sufferer helpless. Words such as 'frustration' are appropriate. In the New Testament, as in the Old, particular groups of people and also the creation in general feel these pains, terrors and tremblings at the approach of the day of reckoning.

But for all its intensity and horror, the image clearly is employed sometimes precisely because the pain of child-birth is a positive pain, a pain with a goal, a productive pain. Just what is produced varies from passage to passage, but facets of the Messiah and the Messianic age are frequently in mind.

Finally it seems likely that the image is used because the course of childbirth is not merely a flash of pain, but a process. The inescapability of the sequence of events once the process begins, but also the repetitive nature of the waves of pain, make it an appropriate image for the Markan Jesus' ideas about the end times.

The imagery of birth-pangs is found in the whole sweep of the biblical writings from Genesis to Revelation. By

28In the Roman Gentile world at least, the father was probably not present at the delivery, but was apparently close at hand, expected to take time off from regular duties, and to be acquainted with the details. See S. Dixon, The Roman Mother (London: Croom Helm, 1988) 106-107, 237-240. Of particular interest is a section of narrative from Aulus Gellius: '... all of us who were there at the time...entered along with him. He embraced the man and congratulated him... When he had finished asking how long the labour had lasted and how difficult the birth had been, and heard that the girl was having a rest, exhausted by her effort and long period without sleep, he started to chat at greater length...', Aulus Gellius, 21.1, translated in J.F. Gardner and T. Weidemann (eds.), The Roman Household: A Sourcebook (London: Routledge, 1991) 104. 
the time we get to Revelation, however, the dominant image has been turned somewhat on its head. The dominant image in the Old Testament prophets was the devastating effect that the judgement of God on the day of the Lord would have on the opponents of YHWH. They would be struck with panic and terror, and rendered like a woman in childbirth. In Revelation, certainly God is still powerful in battle. But the book of Revelation is not dominated by a fierce warrior but by a slain Lamb. And, in chapter 12, instead of the fierce host of the Lord thundering into battle against a foe who is so humiliated as to act like a pregnant woman in the throes of labour, it is rather the Enemy who parades with all the ferocity, as a dragon, and it is Salvation that comes through the humiliation of birthpangs and child-birth. 